\title{
Analysis of Spatial and Temporal Changes in Land Uses and its Implications to the Conservation of Eastern Selous-Niassa Transfrontier Conservation Areas (TFCA)
}

\author{
Adili Y. Zella ${ }^{1 *}$, Saria Josephat ${ }^{2}$, and Yohana Lawi ${ }^{2}$
}

${ }^{1}$ Department of Economic Studies, The Mwalimu Nyerere Memorial Academy (MNMA)-Zanzibar, Zanzibar, Tanzania

${ }^{2}$ Department of Environmental Studies, Faculty of Science, Technology and Environmental Studies, Open University of Tanzania, Dar es Salaam, Tanzania

*Corresponding Author: Adili Y. Zella, Department of Economic Studies, The Mwalimu Nyerere Memorial Academy (MNMA)-Zanzibar, P.O Box 307, Zanzibar, Tanzania, Tel: +255242250315 (or) +255787260448; E-mail: zellahadil@gmail.com (or)adil.zellah@mnma.ac.tz

Received: 12 July 2017; Accepted: 22 August 2017; Published: 05 September 2017

\begin{abstract}
This paper discusses the less known spatial and temporal changes that have occurred over a period of 30 years in land use and land cover and their impacts on terrestrial ecosystem services of Selous - Niassa TFCA. Objectives of the study were to analyze the spatial and temporal changes of land use/cover, estimate amount of trees loss, and analyse wood balance. The study employs field survey, remote sensing and GIS techniques were employed to assess spatio-temporal dynamic of land use/cover. The study has revealed that there has been a significant land use and vegetation cover transformation from one class to another. For the period between 1986 and 1997 the area under closed woodland, open woodland, grassland, built up area, and cultivated land increases by $1.14 \%, 0.62 \%, 2.92 \%$, $0.06 \%$, and $2.17 \%$ respectively. Likewise, bushland and water decreased by 6.86 and 0.04 respectively. For the period between 1997 and 2005, the closed woodland, open woodland, and bushland declined by $9.65 \%, 8.41 \%$, and $5.23 \%$ respectively. For the same period of time, grassland, water, built up area, and cultivated land increased by $5.3 \%, 0.01 \%, 0.29 \%$, and $17.7 \%$ respectively. Moreover, for the period between 2005 and 2016, the closed woodland, open woodland, grassland, water, and cultivated area declined by $0.91 \%, 4.65 \%, 8.25 \%, 0.02 \%$ and $1.53 \%$ respectively. For the same period of time, bushland and built up area increased by $15.27 \%$ and $0.08 \%$ respectively. Also, the results revealed gain of trees regenerated in the study area during the period 1986 - 1997 with


an average of 3.5 million trees per year. Besides, there was rampant conversion of woodland in the study area during the period 1997 - 2016 with average loss of 27 million trees per year. Wood supply in the study area for the year 2016 is at least 25 times the average demand per year per capita. Conversely, the trend of wood supply from 1986 to 2016 shows dramatic deforestation of the area which implies tragedy of commons and is the public property where there are no control policies or rules. The study recommends an emergence of reviewing management and conservation strategies is unexceptional if we need sustainability of Selous-Niassa TFCA.

Keywords: Land use and land cover change (LULCC); Ecosystem services; Tree loss; Wood balance

\section{Introduction}

\subsection{Background information}

Land use and land cover change (LULCC) calls for special attention since humans have been modifying land to obtain food and other essentials for thousands of years, but current rates, extents and intensities of LULC changes are far greater than ever in history [1], driving unprecedented changes in ecosystems and environmental processes at local, regional and global scales. LULCC can occur through the direct and indirect consequences of anthropogenic activities to secure their economic and social needs. Burning of areas to develop the availability of wild game as well as cultivated land, resulting in extensive clearing such as deforestation and earth's terrestrial surface management that takes place today [2]. Many transfrontier conservation areas (TFCAs) are unexceptional from these challenges as they consists of various levels of protected areas (PAs) from strict protection (includes national parks and game reserves) to weak protection (open areas, game controlled areas and wildlife management areas) which shape level of LULCC. For instance, most wildlife protected areas in East Africa are unfenced and wildlife movements are borderless; hence, the dispersal areas connecting two or more PAs depends on the level of protection which can trigger sustainability level of wildlife, habitat and ecosystem services provided by that PA.

LULCC is a complex process which influenced by the jointly interactions between environmental and other social factors at different spatial and temporal scales [3, 4]. More recently, industrial activities and developments, the socalled industrialization, has encouraged the concentration of population within urban areas. This is called urbanization, which includes depopulation of rural regions along with intensive farming in the most productive lands and the abandonment of marginal lands [2]. These conversions and their consequences are obvious around the world and it has been becoming a disaster around the metropolitan areas in developing countries. These changes encompass the greatest environmental concerns of human populations today, including climate change, biodiversity loss and the pollution of water, soils and air. Monitoring and mediating the negative consequences of LULCC while sustaining the production of essential resources has therefore become a major priority of researchers and policymakers around the world.

\subsection{Problem Statement}

Households living in all terrestrial wildlife ecosystems like corridors depend heavily on services provided by those ecosystems for their livelihoods. LULCC can greatly alter the provision of ecosystem services. Land Conversion to human utilization introduces the risk of undermining human wellbeing and long term sustainability [5]. Particularly, it is considered to be one of the drivers of global environmental change [6]. Selous - Niassa ecosystem is not exceptional from this scenario as it connect two terrestrial miombo protected areas (Selous Game Reserve in 
Tanzania and Niassa Game Reserve in Mozambique) to form transfrontier conservation area (TFCA) by a corridor which occupies an area of $14,625.6 \mathrm{~km}^{2}$ that stretches for about 120-180 km and extending across southern Tanzania and the Mozambique border [7]. The corridor dwellers are the one responsible for conversion of habitat to suit their livelihood.

Transformation of ecosystems into other land use categories, primarily the conversion of various vegetation covers to agricultural land and urban areas, impacts water flows and the biogeochemical cycle, and is closely linked to climate change $[8,9]$. The joint effects of land use and climate change are perceived as the most important driver of biodiversity loss. Because biodiversity is known to represent a key prerequisite for the functioning of an ecosystem and delivery of bundles of ecosystem services [10].Land use change may undermine regulatory capacities of the ecosystems for example in terms of the ability to avoid and minimize hazards [5]. A number of risks initiated by land use change or its consequences originate in diminished land productivity, land degradation, disruption of water regime, water contamination, or extra losses of biodiversity [6].

Biodiversity has been diminishing considerably by land change. While lands change from a primary forested land to a farming type, the loss of forest and wildlife species within deforested areas is immediate and huge [2].According to Ellis et al. [2] the habitat suitability of forests and other ecosystems surrounding those under intensive use are also impacted by the fragmenting of existing habitat into smaller pieces, which exposes forest edges to external influences and decreases core habitat area.

The conversion of tropical forest to grassland disrupts the herbivores food chain of different sizes according to their dependent feeding structure and altering of many wildlife species; for example disappearances of "ecotones" (area which separate grassland and wooded grass land) which is the living habitat of some antelopes [11]. LULCC, particularly natural forest alteration makes soils vulnerable to a massive increase in windy and water soil erosion forms, particularly on steep topography. When accompanied by fire, also pollutants to the atmosphere are released. Soil fertility degradation within time is not the only negative impact; it does not only cause damage to the land suitability for future farming, but also releases a huge amount of phosphorus, nitrogen, and sediments to aquatic ecosystems, causing multiple harmful impacts of sedimentation and eutrophication. Thus, this study intended to analyse spatial and temporal LULCC of eastern Selous-Niassa TFCA by estimating habitat conversion area into other activities, amount of trees loss and wood balance.

\subsection{Objectives}

1.3.1 Main objective: The main objective of this study was to analyse spatial and temporal habitat conversion of eastern Selous-Niassa TFCA.

1.3.2 Specific objectives: Specifically the study intends to:

- $\quad$ analyse LULCC of eastern Selous-Niassa TFCA from 1986 to 2016

- $\quad$ estimate amount of trees loss of eastern Selous-Niassa TFCA from 1986 to 2016

- $\quad$ analyse wood balance of corridor dwellers of eastern Selous-Niassa TFCA 


\subsection{Justification of the study}

1.4.1 Significance of study findings: The Study findings will help stakeholders of Transfrontier Conservation Areas (TFCAs) especially Selous-Niassa TFCA to reveal problems of land uses facing them. These stakeholders include the public, researchers, natural resources extension officers, agriculturalists, policy makers, planners, decision makers, game wardens, park rangers, conservators and all other environmental related experts. Furthermore, the study findings will be useful to stakeholders for knowledge generation and proposing solutions at local, national and international levels on issues related to management of TFCAs. Additionally, the study findings will provide room to researchers for further studies.

1.4.2 Why study transfrontier conservation areas (TFCAs): Political boundaries that demarcate country borders were historically drawn for reasons based on national security and strategic interests, colonial land claims, geological and other riches, and convenience, never with conscious thought of maintaining ecological integrity. And so today a political map of the world shows continents carved into a jig-saw puzzle of countries, each with its own pattern of land use, political priorities, and management styles. Even so, historical coincidence has often left conservation areas in different countries adjoining each other, separated by fences or varying ideologies, resulting in fragmented ecosystems or disrupted ecosystem processes. The fragmented systems lead to a loss of ecological resilience and a steady attrition of species over time. By taking a broader view, a regional view, and jointly managing these natural assets for regional benefit, the cons caused by arbitrary political lines drawn for historical reason can be trounced. Ecological benefits; socio-economic and cultural benefits; collaboration and partnerships; and regional peace, harmony and stability are some of the benefits which can be resulted from collaboration across boundaries and adopting a regional approach in natural resource management.

1.4.3 Why study Selous- Niassa TFCA: The study was done in Selous-Niassa TFCA due to the following reason: (i) scanty information of study area interests which is eastern part of the corridor also known as Selous -Masasi compared to western part; (ii) huge area coverage in Africa as the largest trans-boundary natural dry forest ecoregions covering approximately $154.000 \mathrm{~km}^{2}$ with a critical gap between these protected areas that stretches for about 120-180 km and extending across southern Tanzania and the Mozambique border. Through a network of protected areas of various categories of protection, an area of $110,000 \mathrm{~km}^{2}$ of this ecosystem is presently under conservation [5]; (iii) wildlife migration and richness as it constitutes one of the largest elephant ranges in the world and contains half of the world remaining wild dog population, supports a large number of other globally significant, threatened and CITES listed fauna and flora species [1]; (iv) there was no legal protection of wildlife corridors before enaction of wildlife Act of 2009; (v) there was no signed memorandum of understanding between Tanzania and Mozambique concerned protection of the ecosystem before May 2015; and (vi) established wildlife management areas (WMAs) which act as a buffer zone to core protected areas to help conservation of wildlife corridor by involving local communities. WMAs established are bordering Selous, Msanjesi and Lukwika-Lumesule game reserves (MAGINGO WMA, NDONDA and MCHIMALU proposed WMAs respectively) within Liwale, Nachingwea/Masasi and Nanyumbu districts respectively in Tanzania whereas people are living inside Niassa national reserve in Mozambique [12]. 
2. Materials and Methods

\subsection{Materials}

2.1.1 Description of the study area: The study was carried out in eastern Selous-Niassa TFCA with an area of 1, 462, 560 hectares called Selous-Niassa wildlife corridor (SNWC) which extends across southern Tanzania into northern Mozambique between $10^{\circ} \mathrm{S}$ to $11^{\circ} 40^{\prime} \mathrm{S}$ with north-south length of 160 to $180 \mathrm{~km}$ (Figure 1). SNWC comprises of two parts, western part (administratively passes in Namtumbo and Tunduru Districts of Ruvuma regions in southern Tanzania) and eastern part (administratively passes in Liwale, Nachingwea, Masasi, and Nanyumbu Districts). This study concentrated in eastern part. In eastern SNWC, migration of elephants, buffalos and zebras has been observed $[12,13]$. Two migratory routes have been identified as follows:

- From Selous through Nahimba, Nakalonji, Mbondo, Kilimarondo, Matekwe and Kipindimbi proposed game reserve (GR) in Nachingwea District and then via Msanjesi, Mkumbalu, Sengenya, Nangomba and Nanyumbu in Nanyumbu District to Lukwika-Lumesule GR and then crosses Ruvuma River to the Niassa GR.

- From Selous to Kiegei, Namatumu, Kilimarondo in Nachingwea then along Mbangala and Lumesule rivers to Mchenjeuka and Mitanga in the Lukwika-Lumesule GR, from where they cross the Ruvuma River to the Niassa Reserve.

These routes forms SNWC called Selous-Masasi corridor includes the Msanjesi (2,125 ha) and the LukwikaLumesule (44,420 ha) GRs in Masasi and Nanyumbu Districts respectively and areas of Liwale, Nachingwea, Masasi and Tunduru Districts.

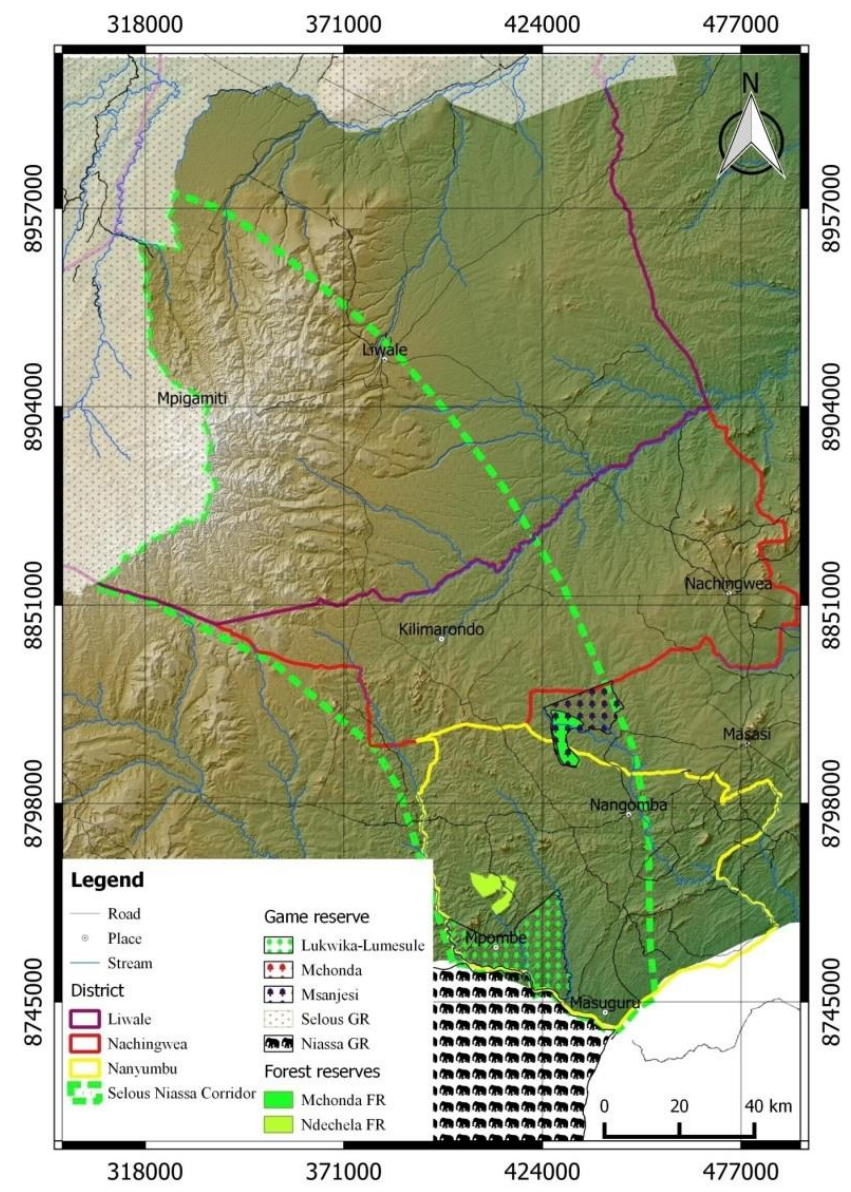

Figure 1: The Map of the study area. 
The study area comprise wildlife management areas (WMAs) bordering Selous, Msanjesi and Lukwika-Lumesule game reserves (MAGINGO WMA, NDONDA and MCHIMALU proposed WMAs respectively) which are within Liwale, Nachingwea/Masasi and Nanyumbu Districts respectively. In this study three villages namely Mpigamiti, Kilimarondo, andMpombe within MAGINGO WMA and NDONDA and MCHIMALU proposed WMA were purposely selected for ground Truthing for the study.

\subsection{Methods}

Spatial data includes satellite images and digital elevation model (DEM) downloaded from USGS - GLOVIS.

2.2.1 Data analysis: To analyse spatial and temporal changes in land use and land cover in easternSelous - Niassa TFCA from 1986-2016.The land cover change detection analysis was conducted based on the following steps:

(i)Satellite image selection and acquisition: Appropriate satellite imagery acquisition was done with highly consideration of cloud cover, the seasonality and phonological effects [14]. Clouds free satellite images with the interval not less than five years from 1986 to 2016 (Table 1) were used in assessing temporal and spatial variation of land use/cover change in the study area.

\begin{tabular}{|l|l|l|l|l|l|}
\hline Year & Satellite & Sensor & Path/Row & Acquisition date & Cloud cover (\%) \\
\hline $\mathbf{1 9 8 6}$ & Landsat 5 & TM (SAM) & $166 / 67$ & $19 / 8 / 1986$ & 0 \\
\hline & Landsat 5 & TM (SAM) & $166 / 68$ & $30 / 9 / 1984$ & 0 \\
\hline & Landsat 5 & TM (SAM) & $167 / 67$ & $21 / 8 / 1990$ & 5 \\
\hline $\mathbf{1 9 9 7}$ & Landsat 5 & TM (SAM) & $166 / 67$ & $14 / 6 / 1997$ & 7 \\
\hline & Landsat 5 & TM (SAM) & $166 / 68$ & $20 / 8 / 1998$ & 8 \\
\hline & Landsat 5 & TM (SAM) & $167 / 67$ & $27 / 12 / 1996$ & 7 \\
\hline $\mathbf{2 0 0 5}$ & Landsat 5 & TM (BUMPER) & $166 / 67$ & $10 / 10 / 2005$ & 10 \\
\hline & Landsat 5 & TM (BUMPER) & $166 / 68$ & $23 / 6 / 2006$ & 1 \\
\hline & Landsat 5 & TM (BUMPER) & $167 / 67$ & $30 / 8 / 20058$ & 8 \\
\hline $\mathbf{2 0 1 6}$ & Landsat 8 & OLI-TIRS & $166 / 67$ & $8 / 10 / 2006$ & 0.28 \\
\hline & Landsat 8 & OLI-TIRS & $166 / 68$ & $8 / 10 / 2016$ & 0 \\
\hline & Landsat 8 & OLI-TIRS & $167 / 67$ & $13 / 9 / 2006$ & 0.8 \\
\hline
\end{tabular}

Table 1: Satellite Imagery Data.

Image Pre-processing: To ensure accurate identification of temporal changes and geometric compatibility with other sources of information, images were pre-processed whereby geo-correction was conducted to rectify precisely matching of images. Band stacking and Images enhancement was performed using different color composite band combination and its contrast was stretched from minimum to maximum to reinforce the visual interpretability of images. Images were registered to the UTM map coordinate system, Zone 36 South, Datum Arc 1960.

(ii)Preliminary image classification and ground trothing:Supervised image classification using Maximum Likelihood Classifier (MLC) was conducted to create base map. Data from ground truth were used to formulate and 
confirm different cover classes existing in the study area. Training sites were identified by inspecting an enhanced color composite imagery. Areas with similar spectral characteristics were trained and classified.

Supervised classification by using Semi-automatic Classification Plug-in (SCP) available in QGIS 2.12.1 was conducted. The process involved selection of regions of interest (ROI) on the image, which represent specific land classes to be mapped. During Supervised Classification, maximum of seven distinct land cover classes were identified (Table 3) which are; Closed woodland (CWD), Open woodland (OWD), Bushland (BS), Grassland (GL), Water (WTR), Built up area (BLT) and Cultivated land (CL).

(iii)Final image classification and accuracy assessment:Kappa coefficient statistics was used to assess the accuracy of final image classification.

Where $\mathrm{N}$ is the total number of sites in the matrix, $\mathrm{r}$ is the number of rows in the matrix,

$$
K=\frac{N \sum_{i=1}^{r} x_{i i}-\sum_{i=1}^{r}\left(x_{i+} \times x_{+i}\right)}{N^{2}-\sum_{i=1}^{r}\left(x_{i+} \times x_{+i}\right)}
$$

$x_{\mathrm{ii}}$ is the number in row $\mathrm{i}$ and column $\mathrm{i}, x_{\mathrm{+}} \mathrm{is}$ the total for row $\mathrm{i}$, and $x i+$ is the total for column.

The classified maps show good agreement with the real world as indicated in Table 2.

\begin{tabular}{|l|l|l|l|l|}
\hline Year & $\mathbf{1 9 8 6}$ & $\mathbf{1 9 9 7}$ & $\mathbf{2 0 0 5}$ & $\mathbf{2 0 1 6}$ \\
\hline Overall accuracy (\%) & $98 \%$ & $82 \%$ & $89 \%$ & $92 \%$ \\
\hline Kappa statistic & 0.97 & 0.79 & 0.92 & 0.91 \\
\hline
\end{tabular}

Table 2: Accuracy assessment.

\begin{tabular}{|l|l|}
\hline Land cover class & Description \\
\hline Closed woodland & $\begin{array}{l}\text { Area of land covered low density trees forming open habitat with plenty of } \\
\text { sunlight and limited shade }\end{array}$ \\
\hline Open woodland & $\begin{array}{l}\text { Area of land covered with low density and scattered trees with crop } \\
\text { cultivation activities }\end{array}$ \\
\hline Bushland & Area dominated with bushes and shrubs \\
\hline Grassland & Land area dominated by grasses \\
\hline Water & $\begin{array}{l}\text { Area within body of land, of variable size, filled with water, localized in a } \\
\text { basin, which rivers flow into or out of them (Lake/Dam) }\end{array}$ \\
\hline Built up area & Man made infrastructure (roads and buildings) and settlement \\
\hline Cultivated land & Farm with crops and harvested cropland \\
\hline Unclassified & $\begin{array}{l}\text { Area with no input data or insufficient information which has been missed } \\
\text { due to several reason including clouds, clouds shadow, darkness, and sensor } \\
\text { dysfunctioning }\end{array}$ \\
\hline
\end{tabular}

Table 3: Land use/cover classification scheme. 
(iv) Landuse and land covers change detection:Post classification comparison was used to quantify the extent of land cover changes over the period 1986 - 2016. Post classification comparison sidesteps the difficulties associated with the analysis of the images that are acquired at different times of the year, or by different sensors and results in high change detection accuracy [15]. The estimation for the rate of change for the different land covers was computed based on the following formulas [11].

\% cover change $=$

$$
\frac{\text { Area }_{\text {iyear } x}-\text { Area }_{\text {iyear } x+1}}{\sum_{i=1}^{n} \text { Area }_{\text {i year } x}} \times 100
$$

\section{$\underline{\text { Area }_{\text {i year } x-\text { Area }_{\text {i year } x+1}}}$}

Annual rate of change $=$

tyears

$\%$ Annual rate of change $=$

$$
\frac{\text { Area }_{\text {iyear } x}-\text { Area }_{\text {iyear } x+1}}{\text { Area }_{\text {i year } x} \times t_{\text {years }}} \times 100
$$

Area $_{i \text { year } x}$ is the area of cover $i$ at the first date,

Area $_{\mathrm{i} \text { year } x+1}$ is the area of cover $\mathrm{i}$ at the second date,

$\sum^{n}$

$\sum_{i=1}$ Area $_{\text {i year }}$ is the total cover area at the first

$\mathbf{t}_{\mathbf{y e a r s}}$ is the period in years between the first and second scene acquisition dates

(v) To estimate amount of trees loss of eastern Selous-Niassa TFCA from 1986 to 2016: Amount of land (in hectares) in the study area that has been converted from closed and open woodlands to other socio-economic activities was used to estimate number trees loss. The study area belongs to southern zone as classified by URT[7]. The number of trees and volume per hectare of the distribution of forest and woody vegetation resources have been classified by employing methodology used by NAFORMA [7] of measuring all trees with Dbh of one $\mathrm{cm}$ and above as shown in table 4.

\begin{tabular}{|l|l|l|}
\hline Districts & Average mean volume $\mathbf{~ m}^{\mathbf{3}} / \mathbf{h a}$ & Average number of trees/ha \\
\hline Liwale, Nachingwea \& Nanyumbu & 49.3 & 1,654 \\
\hline
\end{tabular}

Table 4: Distribution of forests and woody vegetation resources of the study area.

(vi) To analyse wood balance of corridor dwellers of eastern Selous-Niassa TFCA: Current human population of corridor dwellers was estimated based on NBS(National Bureau of Statistics), 2012 census and computing average demand for wood compared with supply from the corridor ecosystem. The study employed NAFORMA [7]baseline information that estimates Tanzania's average demand for wood is $1.39 \mathrm{~m}^{3} /$ year/capita while the annual allowable cut (the sustainable supply) was estimated at $0.95 \mathrm{~m}^{3} /$ year/capita. 


\section{Results and Discussion}

3.1 Spatial and temporal changes in land use and land cover of eastern Selous-Niassa TFCA for period 1986 2016

3.1.1 Land use and land cover assessment: The land use land cover maps for the year 1986, 1997, 2005 and 2016 are presented in Figures 2, 3, 4 and 5. Generally, the maps show variations in cover coverage between the three periods under consideration. Table 5 represents the spatial distribution of land use/cover coverage for the period between 1986 and 2016.

\begin{tabular}{|l|l|l|l|l|l|l|l|l|}
\hline \multirow{2}{*}{ LULC } & \multicolumn{2}{l}{$\mathbf{1 9 8 6}$} & \multicolumn{2}{l}{$\mathbf{1 9 9 7}$} & $\mathbf{2 0 0 5}$ & $\mathbf{2 0 1 6}$ \\
\cline { 2 - 9 } & $\mathbf{( H a )}$ & $\mathbf{( \% )}$ & $\mathbf{( H a )}$ & $\mathbf{( \% )}$ & $\mathbf{( H a )}$ & $\mathbf{( \% )}$ & $\mathbf{( H a )}$ & $\mathbf{( \% )}$ \\
\hline Closed woodland & 227731 & 15.57 & 244348 & 16.71 & 103198 & 7.06 & 89923 & 6.15 \\
\hline Open woodland & 402201 & 27.50 & 411211 & 28.12 & 288176 & 19.70 & 220217 & 15.06 \\
\hline Bushland & 433706 & 29.65 & 333399 & 22.80 & 256911 & 17.57 & 480269 & 32.84 \\
\hline Grassland & 394960 & 27.00 & 437621 & 29.92 & 515143 & 35.22 & 394461 & 26.97 \\
\hline Water & 1431 & 0.10 & 790 & 0.05 & 906 & 0.06 & 646 & 0.04 \\
\hline Built up area & 2532 & 0.17 & 3391 & 0.23 & 7623 & 0.52 & 8851 & 0.61 \\
\hline Cultivated land & 0 & 0.00 & 31799 & 2.17 & 290602 & 19.87 & 268193 & 18.34 \\
\hline TOTAL & $\mathbf{1 4 6 2 5 6 0}$ & $\mathbf{1 0 0}$ & $\mathbf{1 4 6 2 5 6 0}$ & $\mathbf{1 0 0}$ & $\mathbf{1 4 6 2 5 6 0}$ & $\mathbf{1 0 0}$ & $\mathbf{1 4 6 2 5 6 0}$ & $\mathbf{1 0 0}$ \\
\hline
\end{tabular}

Table 5: Land use/cover area distribution between 1986 and 2016.

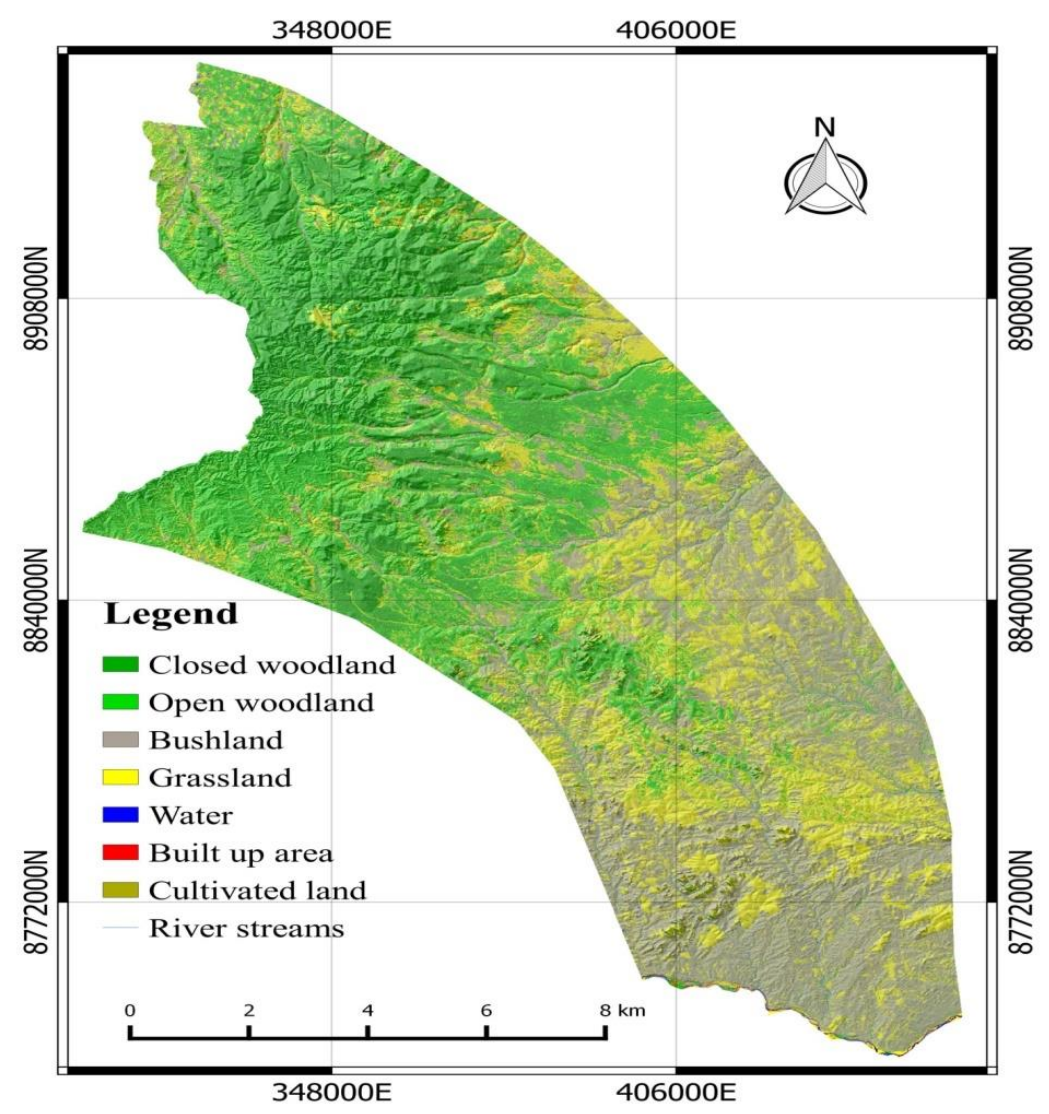

Figure 2:Land use/cover map for eastern Selous - Niassa TFCA 1986. 


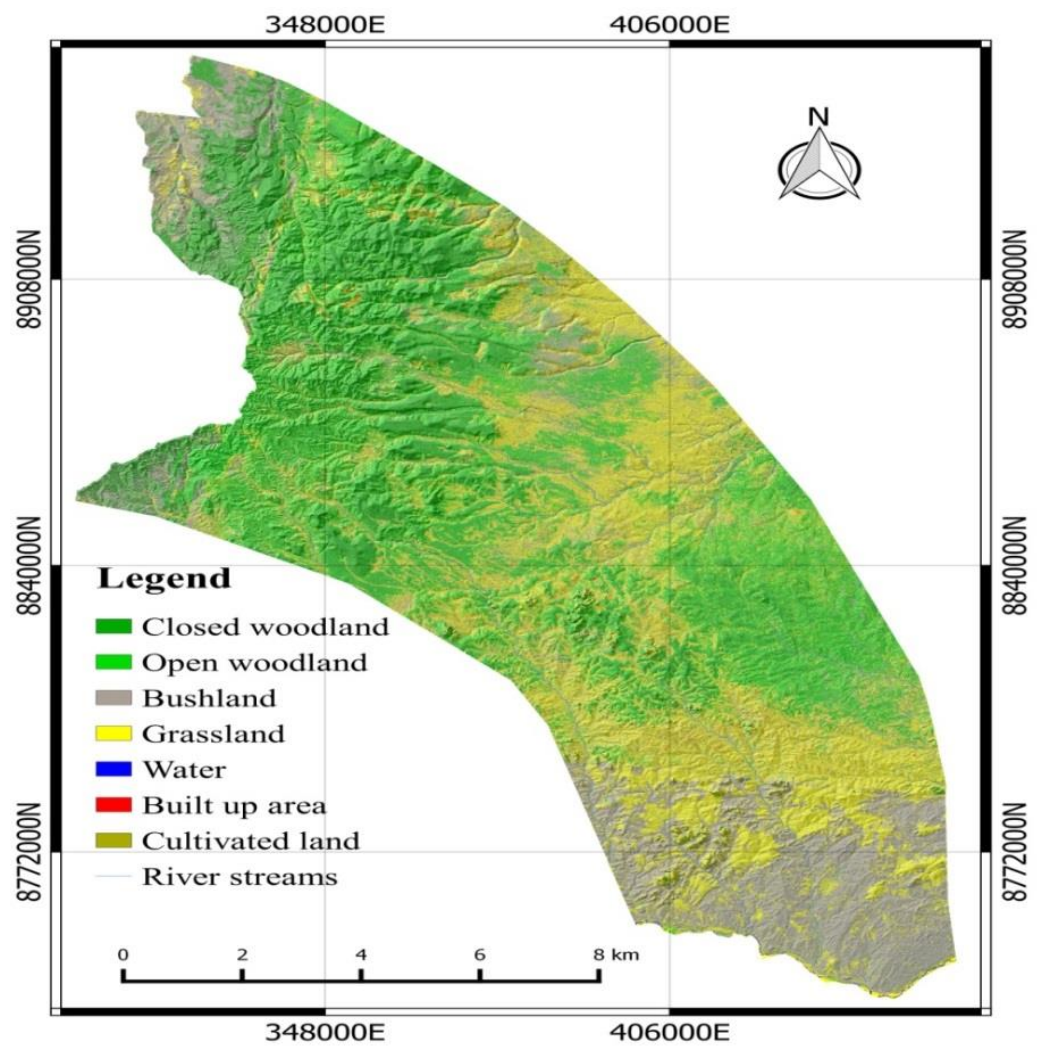

Figure 3: Land use/cover map for eastern Selous - Niassa TFCA 1997.

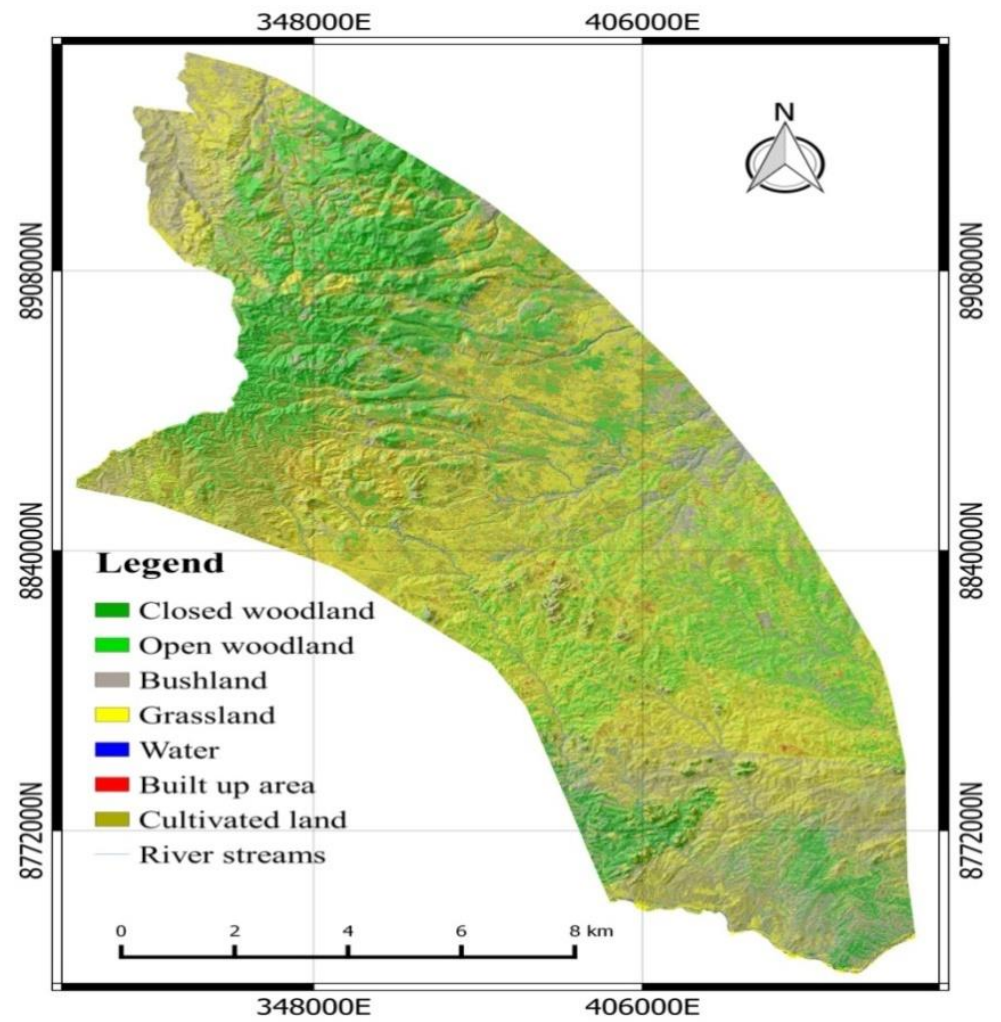

Figure 4: Land use/cover map for eastern Selous - Niassa TFCA 2005. 


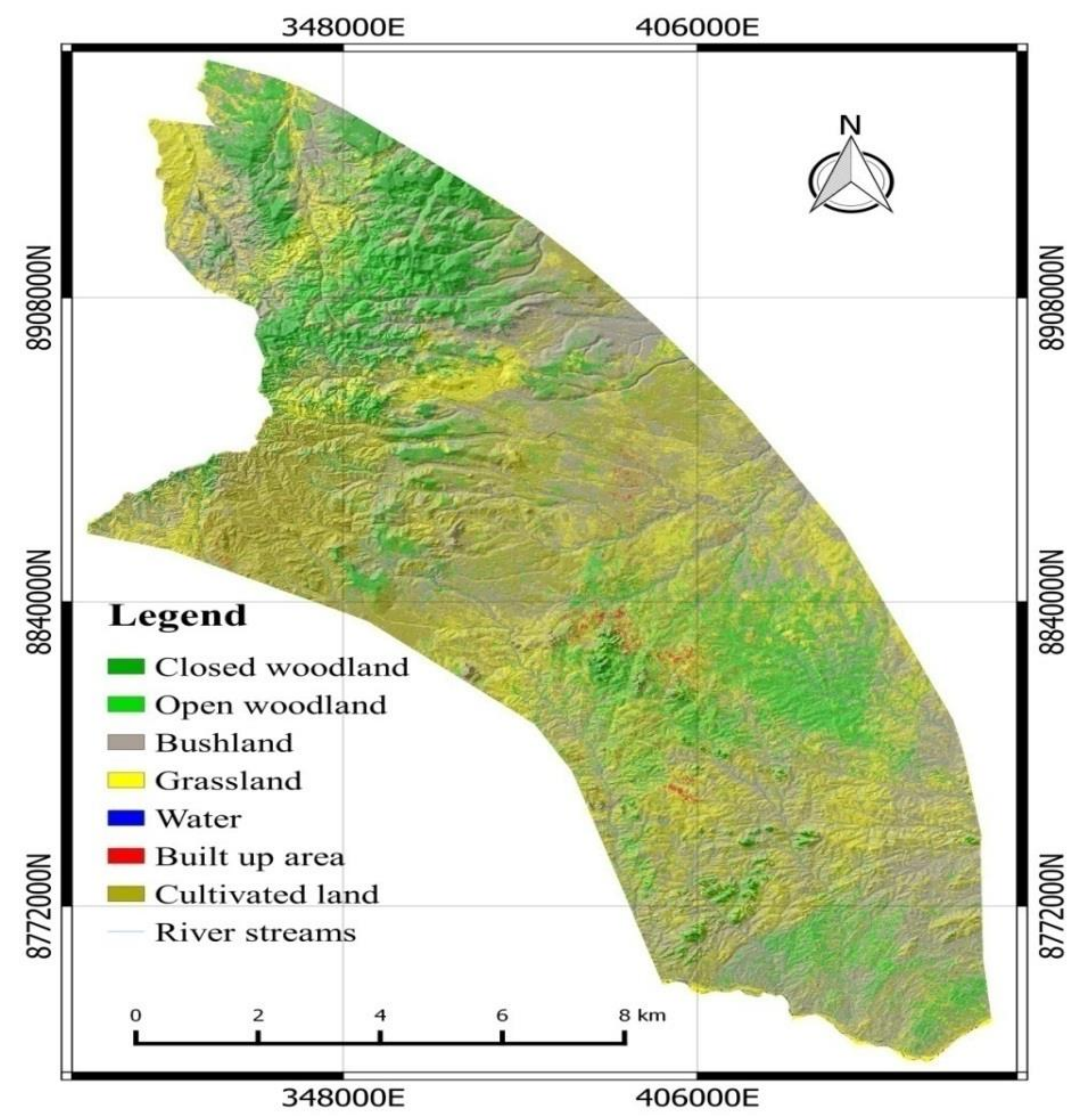

Figure 5: Land use/cover map for eastern Selous - Niassa TFCA 2016.

3.1.2 Land use/cover changes between 1986 and 2016: The extent of land use land cover change including area, percentage area change and percentage annual rate of change are summarised on Table 6. The increased and decreased amount is represented by positive signs (+) and (-) respectively.

\begin{tabular}{|c|c|c|c|c|c|c|c|c|c|}
\hline \multirow[t]{2}{*}{ LULC } & \multicolumn{3}{|c|}{$1986-1997$} & \multicolumn{3}{|c|}{$1997-2005$} & \multicolumn{3}{|c|}{$2005-2016$} \\
\hline & $\begin{array}{l}\text { Area } \\
\text { change } \\
(\mathrm{Ha})\end{array}$ & $\begin{array}{l}\text { Percentage } \\
\text { change (\%) }\end{array}$ & $\begin{array}{l}\text { Annual } \\
\text { Rate of } \\
\text { Change } \\
\text { (Ha/year) }\end{array}$ & $\begin{array}{l}\text { Area } \\
\text { change } \\
(\mathrm{Ha})\end{array}$ & $\begin{array}{l}\text { Percentage } \\
\text { change }(\%)\end{array}$ & $\begin{array}{l}\text { Annual } \\
\text { Rate of } \\
\text { Change } \\
\text { (Ha/year) }\end{array}$ & $\begin{array}{l}\text { Area } \\
\text { change } \\
\text { (Ha) }\end{array}$ & $\begin{array}{l}\text { Percentage } \\
\text { change (\%) }\end{array}$ & $\begin{array}{l}\text { Annual } \\
\text { Rate of } \\
\text { Change } \\
\text { (Ha/year) }\end{array}$ \\
\hline CWD & -16617 & -1.14 & -1511 & 141150 & 9.65 & 11762 & 13275 & 0.91 & 1207 \\
\hline OWD & $\begin{array}{l}-9010 \\
\end{array}$ & $\begin{array}{c}-0.62 \\
\end{array}$ & -819 & 123035 & 8.41 & 10253 & 67959 & 4.65 & 6178 \\
\hline BS & 100306 & 6.86 & 9119 & 76488 & 5.23 & 6374 & -223357 & -15.27 & -20305 \\
\hline GL & -42661 & -2.92 & $\begin{array}{l}-3878 \\
\end{array}$ & -77522 & -5.30 & -6460 & 120682 & 8.25 & 10971 \\
\hline WTR & 641 & 0.04 & 58 & -116 & $\begin{array}{l}-0.01 \\
\end{array}$ & -10 & 260 & 0.02 & 24 \\
\hline BLT & -860 & -0.06 & -78 & -4232 & $\begin{array}{l}-0.29 \\
\end{array}$ & -353 & -1228 & -0.08 & -112 \\
\hline CL & -31799 & -2.17 & -2891 & -258803 & -17.70 & -21567 & 22409 & 1.53 & 2037 \\
\hline
\end{tabular}

CWD = Closed woodland, OWD = Open woodland, BS = Bushland, GL = Grassland, WTR = Water, BLT = Built Up area, and $\mathbf{C L}=$ Cultivated land.

Table 6: Land use/cover change between 1986 and 2016. 
The results (Table 6), indicate that for the period between 1986 and 1997 the area under closed woodland, open woodland, grassland, built up area, and cultivated land increases by $1.14 \%, 0.62 \%, 2.92 \%, 0.06 \%$, and $2.17 \%$ respectively. Likewise, bushland and water decreased by 6.86 and 0.04 respectively. For the period between 1997 and 2005, the closed woodland, open woodland, and bushland declined by $9.65 \%, 8.41 \%$, and $5.23 \%$ respectively. For the same period of time, grassland, water, built up area, and cultivated land increased by $5.3 \%, 0.01 \%, 0.29 \%$, and $17.7 \%$ respectively. Moreover, for the period between 2005 and 2016, the closed woodland, open woodland, grassland, water, and cultivated area declined by $0.91 \%, 4.65 \%, 8.25 \%, 0.02 \%$ and $1.53 \%$ respectively. For the same period of time, bushland and built up area increased by $15.27 \%$ and $0.08 \%$ respectively.

As revealed in Table 6, the decrease of closed woodland, open woodland, and bushland from 1997 to 2016 might be due human encroachments for timber, firewood and medicine, noticeable felling of trees for expansion of agricultural farms; whereas during 1986 to 1997 the increase of the closed and open woodlands happened as a result of famous operation "Uhai" done national wide to curb antipoaching and illegal harvesting of forest and wildlife resources. Also, the cashewnuts cultivated land was included in woodlands and thickets because the land cover is uncertain for this.

Also, the results supported by group discussants during focus group discussions emphasized that, wildfire, cutting trees; drying up trees are serious problems in recent years due to expansion of simsim farming, livestock immigrants, and commercial logging and timbering.

3.1.3 Change detection of different land use/cover: The net change of each land use/cover category is presented in Figure 6, and the change detection matrix for the period between 1986 and 2015 is presented in Tables 7 to 9, clearly reflecting on the land use transformation in the study area.

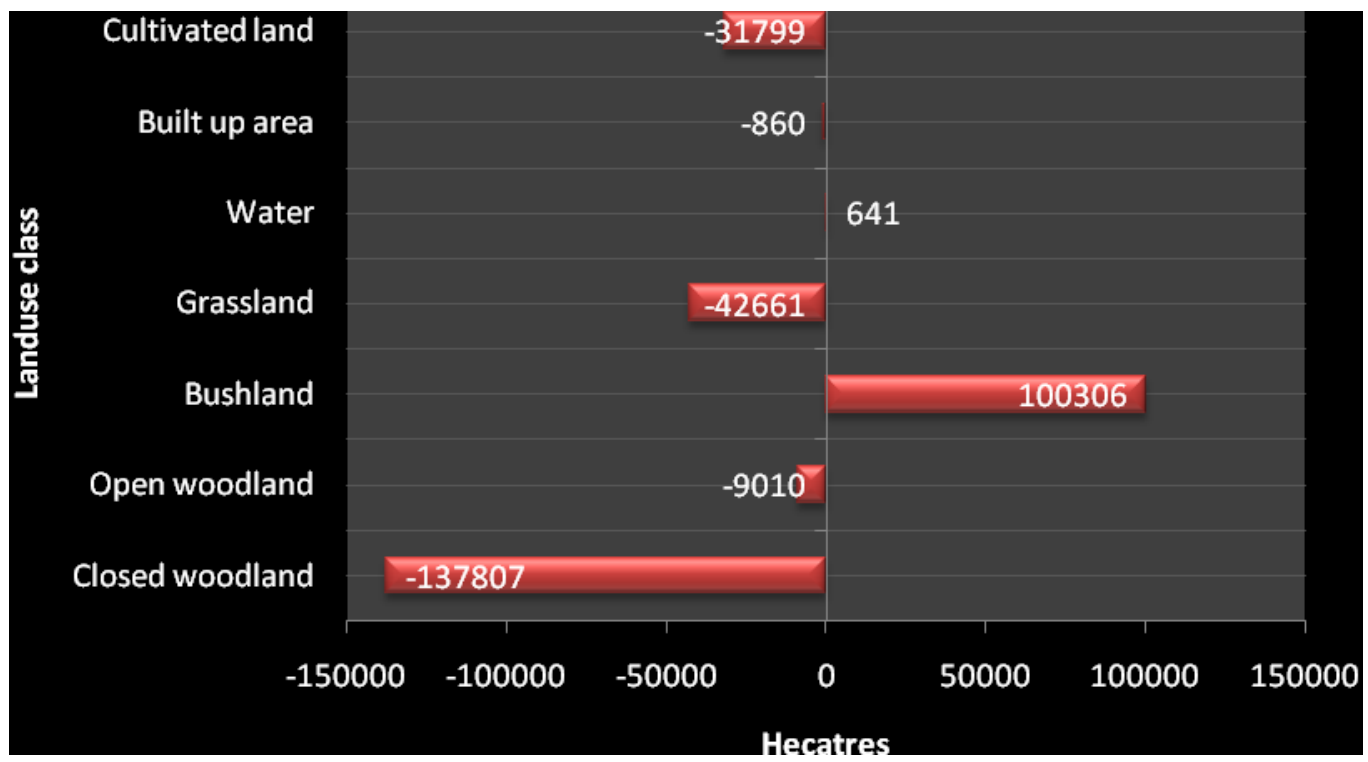

Figure 6: Gain and looses by each land use category between 1986 and 2016. 


\begin{tabular}{|c|c|c|c|c|c|c|c|c|}
\hline \multirow{2}{*}{$\begin{array}{c}\text { Cover in } \\
\mathbf{1 9 8 6}\end{array}$} & \multicolumn{9}{|c|}{ Cover in 1997(Ha) } \\
\cline { 2 - 9 } & CWD & OWD & BS & GL & WTR & BLT & CL & TOTAL \\
\hline CWD & 113076 & 65719 & 15637 & 17197 & 0 & 225 & 1526 & $\mathbf{2 1 3 3 7 9}$ \\
\hline OWD & 81872 & 165795 & 68741 & 84577 & 31 & 772 & 5194 & $\mathbf{4 0 6 9 8 2}$ \\
\hline BS & 20562 & 91588 & 169619 & 146223 & 9 & 514 & 7452 & $\mathbf{4 3 5 9 6 7}$ \\
\hline GL & 28746 & 87920 & 78420 & 187456 & 131 & 1826 & 17493 & $\mathbf{4 0 1 9 9 2}$ \\
\hline WTR & 42 & 25 & 255 & 616 & 489 & 3 & 1 & $\mathbf{1 4 3 1}$ \\
\hline BLT & 35 & 141 & 707 & 1529 & 104 & 153 & 31 & $\mathbf{2 7 0 1}$ \\
\hline CL & 1 & 0 & 1 & 6 & 0 & 0 & 100 & $\mathbf{1 0 7}$ \\
\hline TOTAL & $\mathbf{2 4 4 3 3 4}$ & $\mathbf{4 1 1 1 8 8}$ & $\mathbf{3 3 3 3 8 1}$ & $\mathbf{4 3 7 6 0 4}$ & $\mathbf{7 6 3}$ & $\mathbf{3 4 9 2}$ & $\mathbf{3 1 7 9 8}$ & $\mathbf{1 4 6 2 5 6 0}$ \\
\hline
\end{tabular}

CWD = Closed woodland, OWD = Open woodland, BS = Bushland, GL = Grassland, WTR = Water, BLT = Built Up area, and $\mathbf{C L}=$ Cultivated land.

Table 7: Change detection matrix for the period of 1986 to 1997.

\begin{tabular}{|c|c|c|c|c|c|c|c|c|}
\hline \multirow{2}{*}{$\begin{array}{c}\text { Cover in } \\
\mathbf{1 9 9 7}\end{array}$} & \multicolumn{9}{|c|}{ Cover in 2005 (Ha) } \\
\cline { 2 - 9 } & CWD & OWD & BS & GL & WTR & BLT & CL & TOTAL \\
\hline CWD & 35521 & 71673 & 33529 & 62757 & 0 & 479 & 40457 & $\mathbf{2 4 4 4 1 6}$ \\
\hline OWD & 21869 & 115440 & 43831 & 127066 & 1 & 1970 & 101009 & $\mathbf{4 1 1 1 8 8}$ \\
\hline BS & 32885 & 39815 & 102169 & 104523 & 6 & 1063 & 52920 & $\mathbf{3 3 3 3 8 1}$ \\
\hline GL & 12481 & 57906 & 74047 & 200868 & 450 & 3376 & 88469 & $\mathbf{4 3 7 5 9 6}$ \\
\hline WTR & 0 & 0 & 0 & 343 & 447 & 0 & 0 & $\mathbf{7 9 0}$ \\
\hline BLT & 80 & 229 & 292 & 1830 & 2 & 167 & 791 & $\mathbf{3 3 9 1}$ \\
\hline CL & 356 & 3178 & 3029 & 17727 & 0 & 568 & 6939 & $\mathbf{3 1 7 9 7}$ \\
\hline TOTAL & $\mathbf{1 0 3 1 9 3}$ & $\mathbf{2 8 8 2 4 2}$ & $\mathbf{2 5 6 8 9 7}$ & $\mathbf{5 1 5 1 1 4}$ & $\mathbf{9 0 6}$ & $\mathbf{7 6 2 3}$ & $\mathbf{2 9 0 5 8 6}$ & $\mathbf{1 4 6 2 5 6 0}$ \\
\hline
\end{tabular}

CWD = Closed woodland, OWD = Open woodland, BS = Bushland, GL = Grassland, WTR = Water, BLT = Built Up area, and $\mathbf{C L}=$ Cultivated land.

Table 8: Change detection matrix for the period of 1997 to 2005.

\begin{tabular}{|l|l|l|l|l|l|l|l|l|}
\hline \multirow{2}{*}{$\begin{array}{l}\text { Cover in } \\
2005\end{array}$} & \multicolumn{9}{|c|}{ Cover in 2016 } \\
\cline { 2 - 9 } & CWD & OWD & BS & GL & WTR & BLT & CL & TOTAL \\
\hline CWD & 30929 & 20520 & 24539 & 16728 & 9 & 135 & 10415 & $\mathbf{1 0 3 2 7 5}$ \\
\hline OWD & 23689 & 73670 & 83706 & 62077 & 8 & 835 & 44175 & $\mathbf{2 8 8 1 6 0}$ \\
\hline BS & 9899 & 33202 & 113970 & 70239 & 31 & 538 & 29019 & $\mathbf{2 5 6 8 9 7}$ \\
\hline GL & 14772 & 64418 & 168122 & 170195 & 269 & 3999 & 93340 & $\mathbf{5 1 5 1 1 4}$ \\
\hline WTR & 0 & 0 & 0 & 587 & 320 & 0 & 0 & $\mathbf{9 0 6}$ \\
\hline BLT & 148 & 452 & 1740 & 2809 & 1 & 410 & 2062 & $\mathbf{7 6 2 3}$ \\
\hline CL & 10482 & 28025 & 88165 & 71805 & 8 & 2933 & 89167 & $\mathbf{2 9 0 5 8 6}$ \\
\hline TOTAL & $\mathbf{8 9 9 1 8}$ & $\mathbf{2 2 0 2 8 7}$ & $\mathbf{4 8 0 2 4 2}$ & $\mathbf{3 9 4 4 3 9}$ & $\mathbf{6 4 6}$ & $\mathbf{8 8 5 0}$ & $\mathbf{2 6 8 1 7 8}$ & $\mathbf{1 4 6 2 5 6 0}$ \\
\hline
\end{tabular}

CWD = Closed woodland, OWD = Open woodland, BS = Bushland, GL = Grassland, WTR = Water, BLT = Built $\mathrm{Up}$ area, and $\mathbf{C L}=$ Cultivated land.

Table 9:Change detection matrix for the period of 2005 to 2016 (Ha). 


\subsection{Amount of trees loss in eastern Selous-Niassa TFCA from 1986 to 2016}

Table 10 shows amount of trees loss in eastern Selous- Niassa TFCA from 1986 to 2016. The results show that, there are intercernal changes of tree loss/gain from 1986 to 2016. The results revealed gain of trees regenerated in the study area during the period 1986 - 1997 with an average of 3.5 million trees per year. The reason behind the results might be due to low population of the area, inaccessible roads, low markets of valuable forests and wildlife resources from the study area, lack of policies for conservation and protection of forest and wildlife resources, and national wide operation "Uhai" which was done in this period. Moreover, there was rampant conversion of woodland the study area during the period 1997-2016 with average loss of 27 million trees per year. This implies that, the loss was due to other socio-economic activities which are environmental harmful but economic rewarding like commercial farming of simsim, cashewnuts, sesame, logging and timbering, artisanal mining, and livestock keeping/gathering. These activities involves clearance of woodlands by using fire and drying of standing trees to remove leaves so as to allow sunlight for crops farming and livestock gathering, and reducing tsetse infections.

\begin{tabular}{|c|c|c|c|}
\hline Years & $\begin{array}{c}\text { Total area converted } \\
\text { (ha) }\end{array}$ & $\begin{array}{c}\text { Total volume } \\
\text { Million } \mathbf{~ m}^{\mathbf{3}}\end{array}$ & $\begin{array}{c}\text { Number of trees } \\
\text { loss/gain (in millions) }\end{array}$ \\
\hline $1986-1997$ & $-25,627$ & -1.3 & -42 \\
\hline $1997-2005$ & $+264,184$ & +13.1 & +437 \\
\hline $2005-2016$ & $+81,234$ & +4.0 & +134 \\
\hline Total & $\mathbf{+ 3 1 9 , 7 9 1}$ & $+\mathbf{1 5 . 8}$ & $+\mathbf{5 2 9}$ \\
\hline
\end{tabular}

Table 10: Amount of trees loss from 1986 to 2016.

\subsection{Wood balance of corridor dwellers of eastern Selous-Niassa TFCA}

Existing amount of trees from 1986 to 2016 (Table 11) used to estimate wood balance by using estimated population of the study area in these periods.

\begin{tabular}{|l|l|l|l|l|l|l|}
\hline Year & $\begin{array}{l}\text { Total } \\
\text { woodland } \\
\text { area (ha) }\end{array}$ & $\begin{array}{l}\text { Total } \\
\text { volume } \\
\text { Million } \mathbf{~ m}^{\mathbf{3}}\end{array}$ & $\begin{array}{l}\text { Number of } \\
\text { trees } \\
\text { (in millions) }\end{array}$ & $\begin{array}{l}\text { Estimated } \\
\text { human } \\
\text { population }\end{array}$ & $\begin{array}{l}\text { Wood balance } \\
\text { (trees/capita/year) }\end{array}$ & $\begin{array}{l}\text { Wood balance } \\
\text { (m3/year/capita) }\end{array}$ \\
\hline 1986 & 629,932 & 31.1 & 1041.9 & 312,081 & 3339 & 99.7 \\
\hline 1997 & 655,559 & 32.3 & 1084.3 & 351,866 & 3082 & 91.8 \\
\hline 2005 & 391,374 & 19.3 & 647.3 & 381,229 & 1698 & 50.6 \\
\hline 2016 & 310,140 & 15.3 & 513 & 437,921 & 1172 & 34.9 \\
\hline
\end{tabular}

Table 11: Existing amount of trees from 1986 to 2016.

The results reveled in Table 11 above shows that, wood supply in the study area for the year 2016 is at least 25 times the average demand per year per capita. This implies that the area is still virgin interms of wood balance that means wildlife habitat is still intact. However, the trend of wood supply from 1986 to 2016 shows dramatic deforestation of the area which implies tragedy of common and is the public property where there is no control policies or rules. The emergence of reviewing management and conservation strategies is unexceptional if we need sustainability of Selous-Niassa TFCA. 


\section{Conclusion and Recommendations}

\subsection{Conclusion}

This study analysed land use and land cover changes in eastern Selous - Niassa TFCA. The findings have revealed that the study area has undergone notable changes in terms of land use and land cover for the period between 1986 and 2016. Local knowledge revealed various factors associated to land use and cover change that includes fire, cultivation, and deforestation. The main factors mentioned as contributing to fire were beekeeping, hunting activities, and local beliefs, while for deforestation include commercial logging and timbering, charcoals production, population growth, expansion of commercial farming and food crops production.

The results indicate that land use and land cover change has a significant impact to the management of biodiversity and maintaining ecosystem services of the TFCA. The greater increase of land use conversion alters wildlife movements, gene flow and stochastic events like fire and climate change. The study concludes that the modification of the land use and cover has resulted in behavioral changes of some wild animals due to changes of their habitats. The study highlights the effects of land use and land-cover changes on number of trees loss and wood balance of the corridor dwellers which shows unsustainable supply.

\subsection{Recommendations}

The study provides the following recommendations for sustainable management and conservation of eastern Selous - Niassa TFCA:

$>$ Formulate user friendly guidelines for protection of wildlife corridors as stipulated in Tanzania Wildlife Conservation Act No. 5 of 2009;

$>$ Formulate new and enhancing existing wildlife management areas (WMAs), participatory forests managements (PFMs) and joint forests managements (JFMs) so as accrued benefits should be higher than protection costs of the existing resources;

$>$ Formulate land use plans of the corridors so as to protect wildlife routes within the corridors;

$>$ Usage of alternatives wood resources so as offset the supply deficit and attain sustainability.

\section{Disclosures}

The authors declare that there is no conflict of interest regarding the publication of this paper

\section{References}

1. Baldus RD, Hahn R, Mpanduji D, Siege L. The selous-niassa wildlife corridor. Tanzania Wildlife Discussion Series (2003): 19.

2. Ellis E, Pontius Jr RG. Land-use and land-cover change-encyclopedia of earth. Environ. Protect 2 (2006): 142-53.

3. Valbuena D, Verburg PH, Bregt AK. A method to define a typology for agent-based analysis in regional land-use research. Agriculture, Ecosystems \& Environment 128 (2008): 27-36. 
4. Rindfuss RR, Walsh SJ, Turner BL, et al. Developing a science of land change: challenges and methodological issues. Proceedings of the National Academy of Sciences of the United States of America 101 (2004): 13976-13981.

5. Baldus RD, Hanh R. The SelousûNiassa wildlife corridor in Tanzania: biodiversity conservation from the grassroots (2009).

6. Jingan S, Jiupai N, Chaofu W, et al. Land use change and its corresponding ecological responses: A review. Journal of Geographical Sciences 15 (2005): 305-328.

7. United Republic of Tanzania (URT). National Forest Resources Monitoring and Assessment of Tanzania Mainland. Ministry of Natural Resources and Tourism, Dar es Salaam (2015).

8. Milad M, Schaich H, Bürgi M, et al. Climate change and nature conservation in Central European forests: a review of consequences, concepts and challenges. Forest ecology and management 261 (2011): 829-843.

9. Schulp CJ, Nabuurs GJ, Verburg PH. Future carbon sequestration in Europe-effects of land use change. Agriculture, Ecosystems \& Environment 127 (2008): 251-264.

10. Millennium Ecosystem Assessment (MA). Ecosystems and Human Well-Being: Current state and Trends. Washington DC (2005).

11. Kashaigili JJ, Majaliwa AM. Implications of land use and land cover changes on hydrological regimes of the Malagarasi River, Tanzania. Journal of Agricultural Science and Applications 2 (2013): 45-50.

12. Pesambili A. Wildlife resources of Lukwika-Lumesule and Msanjesi Game Reserves. WWF-TPO (2003): 12.

13. Ntongani WA, Munishi PKT, Mbilinyi BP. Land use/cover change and socio-economic factors influencing land cover dynamics in the Selous-Niassa wildlife corridor Nachingwea District Tanzania. Proceedings of the sixth TAWIRI scientific conference (2007).

14. Kashaigili JJ, McCartney M, Mahoo HF, et al. Use of a hydrological model for environmental management of the Usangu Wetlands, Tanzania. IWMI (2006).

15. Li RQ, Dong M, Cui JY, et al. Quantification of the impact of land-use changes on ecosystem services: a case study in Pingbian County, China. Environmental Monitoring and Assessment 128 (2007): 503-510.

16. Millennium Ecosystem Assessment. Ecosystems and Human Well-being Biodiversity Synthesis. Washington, DC: World Resources Inst (2005).

(C) This article is an open access article distributed under the terms and conditions of the Creative 